studying women in Europe and the United States with ones that challenged the validity of those questions for the study of women in the Third World.

\title{
Society for French Historical Studies
}

\author{
Laura L. Frader \\ Northeastern University
}

Labor history was alive and well at a conference of the Society for French Historical Studies held at Ohio State University on March 29-31, 1990. In two panels and one plenary session - a total of nine papers-French labor historians examined a variety of issues ranging from representations of labor and workers in socialist thinking, the labor press, and labor congresses, to workers' reactions to the portrayal of work and labor in the Paris Exhibition of 1889, women in unions, and managerial strategies in controlling women workers in the Paris metal trades.

Recently, French labor historians have examined the disjuncture between representations of work in France on the one hand, and workers' own vision and experience of work and labor organization on the other. (See, for example, essays in the excellent collection edited by Steven Laurence Kaplan and Cynthia J. Koepp, Work in France: Representations, Meaning, Organization, and Practice [Ithaca and London, 1986]). Two papers at the conference focused on this theme. Joy Hall (Auburn University), in "Worker and Socialist Responses to the Social Economy Exhibit at the Paris Exposition of 1889," argued that the exhibit, designed to further solidarist ideals of social peace between workers and employers and to promote mutualism for its moral as well as its economic benefits, proved to be a disappointment for workers. Their voices were lost in reformers' efforts to promote management-oriented reform; no place was given to demonstrating the realities of workers' experience. K. Steven Vincent (North Carolina State University), in "Representations of Labor and Workers in Nineteenth-Century French Socialist Thought," traced the ambiguity of French socialist thinking on work from Lafargue's defense of "the right to be lazy" to Fourier's argument that work could be liberating if not fulfilling and Proudhon's idea that a committed, creative labor force, conscious of its moral obligation, could save society from decadence. Vincent argued that socialists idealized the worker-as-hero even when reality suggested differently - although it is true that, as Steven Zdatny (Rice University) pointed out in his comments, the socialists' overidealizing of workers' potential for action was not unusual or unique: all political parties did this. This moralizing tendency spilled over into discussions of women, where the socialists praised the virtues of the femme au foyer. They were less concerned with the exploitation of women in the workplace than they were with the problem of the demise of the home. 
In a controversial paper, "Liberalism, Paternalism and Immigrant Workers: Foreign Labor and Industrial Capitalism in Late-Nineteenth-Century France," David Gordon (University of North Carolina, Charlotte) argued against the view of Gérard Noiriel and others that employer paternalism, far from being beneficial or even benign, enabled capital to exert control over labor. Looking at the paternalistic employers of the French textile cities Roubaix and Mulhouse, Gordon maintained that after 1860 the government's free-trade policies forced French employers to adopt a paternalistic approach to industrial relations in order to attract workers and keep French industry competitive. Paternalistic policies benefited all workers, and immigrant workers were in an especially good position because they were free to leave at any time. Laura Downs (University of Michigan) took a very different position on paternalistic management strategies in "In Search of Modern France: the Vogue of Scientific Management in Interwar Metalworking Factories." Industrial welfarism. carried out through the surintendantes d'usine (women factory supervisors), she argued, was a vehicle through which employers controlled not only women's work but their family lives as well by taking management into the domestic sphere.

In a panel on women, work, and the labor movement in twentieth-century France, Judith Wishnia (State University of New York, Stony Brook) examined "Women in the Civil Service Unions in the Third Republic." She showed that women in civil service unions (in contrast to many industrial unions) were not only active union militantes but were also accepted by male union members. Women civil service workers succeeded in transmitting their feminist consciousness to male members and won the earliest victories for pay equity and maternity leave. Nancy Green (Ecole des Hautes Etudes en Sciences Sociales), in "Art and Industry: the Language of Modernization and Gender in the Garment Trade," examined changing attitudes toward women as producers in the garment trade and as consumers of fashion. She pointed to the image of women as occasionally capricious consumers who nonetheless determined (via their power of demand) the course of the industry. Laura Frader, in "Gender and the French Labor Movement Between the Wars," looked at discussions about women in the unions and labor congresses in the union press of the metal trades and the congresses of the CGT and CGTU in the 1920s. She argued that both men's and women's perceptions of women's work and labor movement activity were shaped by concerns about the French family and women's maternal and reproductive roles that appeared so prominently in the interwar years.

One of the most interesting parts of the conference was a plenary session devoted to "The Future of Labor History: From Proletarianization to Discourses?" with provocative papers by William Sewell (University of Michigan) and Christopher Johnson (Wayne State University) and comments by Michael Hanagan, Michelle Perrot, and William Reddy. Indeed, as a recent debate in the pages of ILWCH (31:1-36) has suggested, U.S. historians have been drawn to the analytical possibilities presented by post-Marxist, post-structuralist, social and cultural theory. Sewell's "Reconceptualizing Labor History: Towards a Post-Materialist 
Rhetoric" contrasted the stagnant (in his view) field of labor studies with the more theoretically exciting field of women's studies which has been more open to poststructuralist social and cultural theory. He called for a new figuration of labor studies that would 1) abandon the notion of production and exchange as a distinct realm of social relations separate from politics and culture; 2 ) equally abandon the fundamental paradigm of the economy as exclusively material (it is also cultural and symbolic); and 3) move beyond old disciplinary boundaries. Christopher Johnson echoed Sewell's plea in "Economic Change, Class Experience and Consciousness: Some Questions After Reading Habermas." Labor historians, argued Johnson, need to approach societies as life-worlds - through the meanings people give to their activities - and in terms of the structures and systems that give them shape. Subjectivity and intentionality are important elements of the constructed world - at least as important as the structures and systems to which they give meaning. Johnson suggested that Habermas provides a lifeline to rescue labor history from its current doldrums.

In fact, current work by U.S. historians in French labor history-especially women's history - has already begun to embody these ideas. Attention to discourses, to representations, and to the assignment of cultural meanings has already begun to inform the work of social historians as they attempt to expand their understanding of the world of workers and of labor movements. These concerns with theory and interdisciplinarity, however, may be particular to the work of historians on this side of the Atlantic. As Michelle Perrot pointed out in her comments, the debates about the use of post-structuralist social and cultural theory in historical analysis that have occurred here are absent in France, probably because the French have distanced themselves from Marxism and because French intellectuals and historians have been much less interested in post-structuralism than their American counterparts.

\title{
Conflict and Cooperation: Comparative Research on the East European Migratory Experience, 1880s-1930s
}

\author{
Donna Gabaccia \\ Mercy College
}

In late April 1990, the University of Bremen's Volkswagen-sponsored project "Conflict and Cooperation: Comparative Research on the East European Migratory Experience, 1880s-1930s" brought together more than fifty scholars from twelve nations in a final conference. Like all the Bremen projects under the direction of Dirk Hoerder, this undertaking began with the premise that labor migrations created multiethnic working classes in industrial centers everywhere; 